\title{
Letter to the Editor: The Effect of Head Loading on Cervical Spine in Manual Laborers
}

\author{
Tarush Rustagi ${ }^{1}$, Siddharth Badve ${ }^{2}$ \\ ${ }^{1}$ Indian Spinal Injuries Centre, New Delhi, India \\ ${ }^{2}$ Geisinger Health System-Lewistown Hospital \& Gray's Woods, State College, PA, USA
}

Dear Editor,

We read with great interest, article by Dave et al. [1] titled "The effect of head loading on cervical spine in manual laborers."

The paper very appropriately highlights the implications of upper cervical accelerated degeneration following head loading activities. This also brings about an important consideration of having an upper limit of permissible weights that should be carried by manual laborers. The functional disability can be profound in relatively young populations who develop this in developing and underdeveloped countries [2]. Badve et al. [3] on a similar pattern performed a cross-sectional study on railway porters and reported a significant increase in the prevalence of OC1C2 osteoarthritis. While the research by Dave et al. [1] analyses the acute plain radiographic implications to head loading on the cervical spine, the article by Badve et al. [3] investigates a more delayed response based on cross-sectional imaging. Other authors have also reported similar findings $[2,4-6]$.

It will be interesting for future studies to assess weight wise effect on cervical spine loading based on morphological parameters like gender, muscle morphology, and so forth. This may form the basis of a concrete guideline for the concerned authorities to make necessary laws. More importantly, it may be useful for educational purposes and promote the use of alternate methods of carrying weight like push carts $[2,6]$. Additionally, eventually, it may aid to develop ergonomic designs or techniques of carrying weights on the head to mitigate the ill effects of head loading like designs to allow weight sharing over shoulders.

We again congratulate the authors to bring forward an important study to highlight this aspect.

\section{Conflict of Interest}

No potential conflict of interest relevant to this article was reported.

\section{References}

1. Dave BR, Krishnan A, Rai RR, Degulmadi D, Mayi S. The effect of head loading on cervical spine in manual laborers. Asian Spine J 2021;15:17-22.

2. Schaeren S, Jeanneret B. Atlantoaxial osteoarthritis: case series and review of the literature. Eur Spine J 2005;14:501-6.

3. Badve SA, Bhojraj S, Nene A, Raut A, Ramakanthan R. Occipito-atlanto-axial osteoarthritis: a cross sec-

Received Apr 30, 2021; Accepted May 1, 2021

Corresponding author: Tarush Rustagi

Department of Spine Surgery, Indian Spinal Injuries Centre, Sector C, Vasant Kunj, New Delhi-110070, India

Tel: +91-8826383705, Fax: +91-8826383706, E-mail: tarush.rustagi@gmail.com 
tional clinico-radiological prevalence study in high risk and general population. Spine (Phila Pa 1976) 2010;35:434-8.

4. Mahbub MH, Laskar MS, Seikh FA, et al. Prevalence of cervical spondylosis and musculoskeletal symptoms among coolies in a city of Bangladesh. J Occup Health 2006;48:69-73.
5. Joosab M, Torode M, Rao PV. Preliminary findings on the effect of load-carrying to the structural integrity of the cervical spine. Surg Radiol Anat 1994;16:393-8.

6. Echarri JJ, Forriol F. Influence of the type of load on the cervical spine: a study on Congolese bearers. Spine J 2005;5:291-6. 